\title{
FENOMENA DEMOKRATISASI LOKAL DI PROVINSI BANTEN
}

\author{
Oleh : \\ Delly Maulana \\ Program Studi Ilmu Administrasi Negara \\ Fakultas Ilmu Sosial dan Ilmu Politik Universitas Serang Raya \\ E-mail : delly_maulana@yahoo.com
}

\begin{abstract}
ABSTRAK
Tulisan ini mengambarkan tentang fenomena demokratisasi lokal di Provinsi Banten pasca diberlakukannya kebijakan desentrasalisasi atau otonomi daerah pada tahun 1999. Kondisi tersebut jelas membawa konsekuensi bagi Provinsi Banten untuk mengatur dan menentukan urusan rumah tangganya sendiri serta merealisasikan terciptanya persamaan politik, akuntabilitas lokal, dan kepekaan lokal di Provinsi tersebut. Namun, fakta membuktikan bahwa penerapan demokratisasi lokal di Provinsi Banten mengalami kemandegan, hal tersebut dikarenakan masih menguatnya posisi elit oligarki di tingkat lokal (keluarga politik) sehingga sirkulasi kekuasaan hanya berputar pada segilintir orang saja.
\end{abstract}

Kata Kunci : Desentralisasi, Demokratisasi Lokal, Oligarki Politik Keluarga

\section{A. PENDAHULUAN}

Penerapan kebijakan desentralisasi saat ini telah berjalan lebih dari empat belas tahun semenjak diberlakukannya Undangundang Nomor 22 Tahun 1999. Semenjak itu pula demokratisasi lokal di Indonesia diterapkan, baik dari penerapan pemilihan kepala daerah dipilih secara perwakilan atau oleh anggota Dewan Perwakilan Rakyat Daerah (DPRD) sampai diterapkannya pemiliahan langsung oleh masyarakat. Selanjuntya, dari DPRD yang hanya sebagai "cap stempel" sampai menjadi sebuah lembaga yang mempunyai kewenangan yang kuat dalam menjalankan fungsi legislasinya, fungsi pengawasannya, dan fungsi anggaran.

Secara subtantif, desentralisasi dalam konsteks politik adalah terjadinya transfer lokus kekuasaan dari pusat ke daerah. Dengan konteks tersebut maka daerah-daerah memiliki kewenangan untuk mengatur dan menentukan urusan rumah tangganya sendiri. Oleh karena itu, dalam menjalankan kewenangannnya tersebut maka mewujudkan demokratisasi di tingkat lokal harus diterapkan secara subatantif, sebab salah satu tujuan dari penerapan desentralisasi adalah terciptanya persamaan politik, akuntabilitas lokal, dan kepekaan lokal di daerah. ${ }^{2}$

$$
\text { Dalam konteks Provinsi }
$$

Banten, penerapan demokratisasi lokal saat ini mengalami kemandegan, hal tersebut dikarenakan masih menguatnya posisi elit oligarki di tingkat lokal (keluarga politik) sehingga sirkulasi kekuasaan

\footnotetext{
${ }^{2}$ Lihat Lili Romli, Pilkada Langsung, Otonomi

Daerah dan Demokrasi Lokal dalam Jurnal Analisis CSIS, 2005, hal 286
} 
hanya berputar pada segilintir orang saja. Kondisi tersebut jelas akan menyebabkan penerapan dari tujuan desentralisasi, yakni terciptanya persamaan politik, akuntabilitas lokal, dan kepekaan lokal tidak akan berjalan secara efektif.

Berdasarkan survey intregritas pemerintah daerah yang dilakukan oleh Komisi Pemberantas Korupsi (KPK), Provinsi Banten mempunyai integritas pemerintah daerah yang rendah dengan nilai skor sekitar 5,66. Sedangkan menurut Transparansi Internasional (TI), Banten masih menunjukkan tingkat korupsi yang tinggi dalam penyelenggaran pemerintahan dengan nilai skor sekitar 4,87. Selain itu, kinerja Provinsi Banten juga dinilai buruk, menurut survey yang dilakukan oleh Kementerian Dalam Negeri pada tahun 2010, Provinsi Banten mendapatkan nilai skor 44,57 dan menempati posisi ke-6 dari ke-7 Provinsi baru hasil pemekaran. ${ }^{3}$

Sejumlah kondisi di atas nampaknya cukup relevan dengan salah satu riset yang dilakukan oleh Pusat Studi Kependudukan dan Kebijakan Universitas Gadjah Mada (PSKK-UGM) yang dirilis tahun 2007. Riset ini bertujuan mengukur "Government Assesment in Banten Province" menghasilkan kesimpulan yang agak mengejutkan dimana terdapat sejumlah indikator yang secara meyakinkan Banten tengah kearah bad governance bukan good governance. Beberapa indikator itu, antara lain : indeks efektivitas pemerintah yang hanya 0,39 ; indeks partisipasi 0,4 ; indeks transparansi

${ }^{3}$ Ismanto, Banten Menuju Keterbukaan Informasi : Best Practice KIP, Proceeding Otda LAB ANE FISIP Untirta, 2011, hal 178
0,33; indeks kapasitas penyampaian informasi 0,44; indeks kualitas Perda 0,47 ; indeks rule of law 0,38 ; indeks kepercayaan publik 0,44 ; dan indeks stabilitas politik 0,6. Nyaris seluruh indikator good governance tersebut di bawah angka 0,5 yang berarti dalam kondisi buruk, bahkan sangat buruk. ${ }^{4}$ Semenetara itu, jika dilihat dari Indonesia Governance Index (IGI) yang dikeluarkan oleh Kemitraan Partnership pada tahun 2013 tentang Provinsi Banten, maka Banten berada dalam rangking ke 17 dari 33 provinsi di Indonesia dengan nilai indeks sebesar 5,81 atau dalam kategori sedang. Ada beberapa prinsip-prinsip dalam kategori yang buruk, yakni prinsip keadilan $(2,90)$, prinsip transparansi $(2,99)$, di arena pemerintah, dan prinsip transparansi $(3,50)$ di arena birokrasi. ${ }^{5}$

Dengan

permasalahan tersebut, maka dalam tulisan ini penulis akan mengambarkan kondisi demokratisasi lokal di Provinsi Banten serta mengkaitkannya dengan fenomena menguatnya posisi elit oligarki (keluarga politik) di Provinsi Banten.

\section{B. Konsep Demokratisasi Lokal}

Dewasa ini demokrasi adalah suatu kata yang sangat terpuji dan telah menjadi tujuan bagi banyak orang dan bangsa di seluruh dunia. Namun demikian, pengertian mengenai demokrasi itu sukar untuk dipahami. Kita mengetahui bahwa demokrasi berasal-nyaris secara eksklusif-dari wilayah politik. Dahl, Coppedge, dan Rainicke

\footnotetext{
${ }^{4}$ IbId hal 179

${ }^{5}$ Lihat Indonesia governance index (IGI), Kemitraan Partnership, 2013
} 
membahasakan bahwa ketika ada yang mendefinisikan demokrasi secara ideal atau juga disebut sebagai definisi populistik tentang demokrasi, yakni sebuah sistem pemerintahan "dari, oleh, dan untuk rakyat" maka pengertian demokrasi demikian tidak pernah ada dalam sejarah umat manusia. Tidak ada pemerintahan dijalankan langsung oleh semua rakyat, adan tidak ada pernah ada pemerintahan sepenuhnya untuk semua rakyat. Dalam praktiknya yang menjalankan pemerintahan bukan rakyat, tapi elite yang jumlahnya jauh lebih sedikit. Juga tidak pernah ada hasil pemernitahan itu untuk rakyat semuanya secara merata, tapi selalu ada perbedaan antara yang mendapatkan jauh lebih banyak dan yang mendapatkan jauh lebih sedikit. Karena itu, ketika pengertian "demokrasi populistik" hendak dipertahankan, Dahl mengusulkan konsep "poliarki" sebagai pengganti dari konsep "demokrasi populistik" tersebut. Poliarki dinilai lebih realistik untuk menggambarkan tentang sebuah fenomena politik tertentu dalam sejarah peradaban manusia sebab poliarki mengacu pada sebuah sistem pemerintahan oleh "banyak rakyat" bukan oleh "semua rakyat", oleh "banyak orang", bukan "semua orang". 6

Dahl membahasakan juga bahwa demokrasi, dalam pengertian poliarki ini, adalah sebuah sistem pemerintahan dengan ciri-ciri berikut ini : adanya kebebasan warga Negara dalam sistem tersebut untuk (1) membantuk dan ikut serta dalam organisasi, (2) berekpresi atau berpendapat, (3) menjadi pejabat

${ }^{6}$ Lihat Menakar Demokrasi di Indonesia : Indeks Demokrasi Indonesia 2009, UNDP hal 10 publik, (4) melakukan persaiangan atau kontestasi di antara warga dalam rangka memperebutkan jabatanjabatan publik penting, memberikan suara dalam pemilihan umum, (6) ada pemilihan umum yang jurdil, (7) adanya sumber-sumber informasi alternatif di luar yang diberikan pemerintah, dan (8) adanya jaminan kelembagaan bahwa setiap kebijakan pemerintah tergantung pada dukungan suara dan bentukbentuk ekspresi keinginan lainnya, dan arena itu harus ada jaminan pemilihan umum secara priodik sehingga setiap kabijakan yang dibuat oleh pemerintah terbuka untuk dievaluasi dan diupertanggungjawabkan dalam pemilihan umum tersebut. ${ }^{7}$ Akhirnya, dengam mempertimbangkan konsep tersebut maka konsepsi demokrasi dapat diukur oleh 3 (tiga) aspek, yakni : (1) Kebebasan Sipil (Civil Liberty), (2) Hak Politik (Political Right), dan (3) Lembaga-lembaga Demokrasi (Institutions of Democratic). ${ }^{8}$

Sementara itu, jika demokrasi dikaitkan dengan desentralisasi atau otonomi daerah maka kadar suatu demokrasi di tingkat lokal dapat ditentukan oleh seberapa besar masyarakat lokal dalam menentukan siapa dari antara mereka yang dijadikan sebagai pejabat publik di tingkat lokal, mengawasi prilakunya, maupun dalam menentukan arah kebijakan publik. Kondisi tersebut diperkuat oleh pernyataan Robert Dahl (1989) yang menyatakan bahwa demokratisasi pada tingkat nasional hanya mungkin akan terbangun jika demokrasi juga berlangsung pada

\footnotetext{
${ }^{7}$ Ibid hal 11

${ }^{8}$ Ibid hal 16
} 
tingkat lokal. Hal ini juga dipertegas oleh Beetham (1996), Manor (1998), Geveta (2001), pemerintah lokal memiliki potensi dalam mewujudkan demokratisasi karena proses desentralisasi mensyaratkan adanya tingkat responsivitas, keterwakilan, dan akuntabiltas yang lebih besar. Sementara Smith, Dahl, dan Mewhood mengatakan bahwa untuk mewujudkan apa yang disebut local accountability, political equity, and local responsiveness, yang merupakan tujuan desentralisasi, di antara prasyarat yang harus dipenuhi untuk mencapainya adalah : pemerintah daerah harus memiliki teritorial kekuasaan yang jelas (legal territory of power); memiliki pendapatan daerah sendiri (local own income); memiliki lembaga perwakilan (local representative body) yang berfungsi untuk mengontrol eksekutif daerah; dan adanya kepala daerah yang dipilih secara langsung oleh masyarakat melalui mekanisme pemilihan umum. $^{9}$

\section{Gambaran Demokratisasi Lokal di Provinsi Banten}

Secara konseptual demokrasi lokal dapat diukur oleh 3 (tiga) aspek, yakni : (1) Kebebasan Sipil (Civil Liberty), (2) Hak Politik (Political Right), dan (3) Lembaga-lembaga Demokrasi (Institutions of Democratic). Dari hasil pengukuran Indeks Demokrasi Indonesia (IDI) pada tahun 2009 di Provinsi Banten menunjukkan bahwa Indeks Demokrasi Provinsi Banten masuk dalam ketegori sedang $(67,98)$ atau

\footnotetext{
${ }^{9}$ Firiyah, Sistem dan Proses Pilkada Secara Langsung dalam Jurnal Analisis CSIS, 2005, hal 297
}

berada di peringkat 16 dari 33 provinsi yang ada di Indonesia. Selanjunya, jika dilihat dari beberapa aspek demokrasi, salah satunya aspek kebebasan sipil maka Provinsi Banten memiliki nilai indeks sebesar 95,46 atau masuk dalam peringkat ke-10 dari 33 provinsi. Sedangkan dalam aspek hak-hak politik, Provinsi Banten memiliki nilai indeks sebesar 49,47 atau masuk dalam peringkat ke-24 dari 33 provinsi. Sementara itu, dalam aspek lembaga demokrasi, Provinsi Banten memiliki indeks sebesar 62,82 atau masuk dalam peringkat ke-21 dari 33 provinsi.

\section{Grafik 1}

\section{Perbandingan IDI Banten dan} Nasional

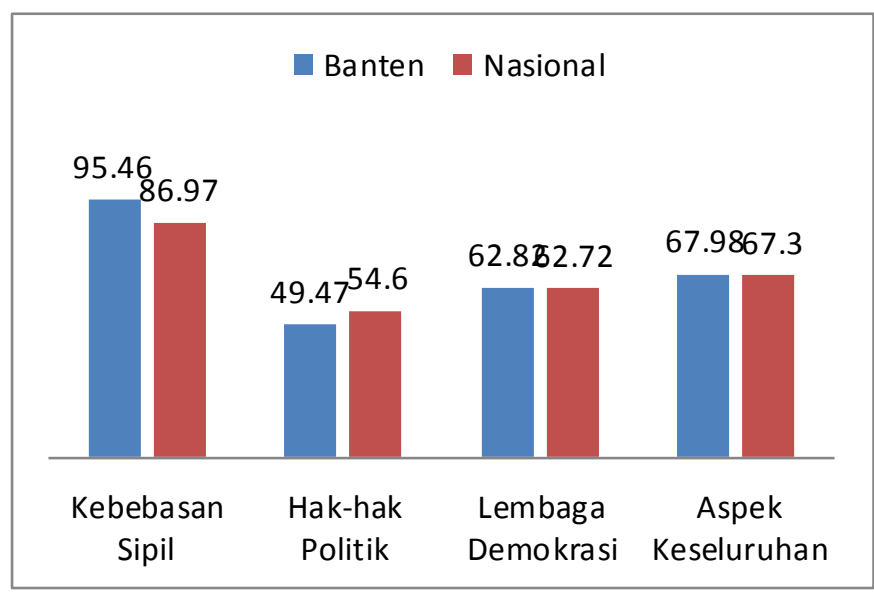

Sumber : Indeks Demokrasi Indonesia Tahun 2009 data diolah

Dari indeks demokrasi di Provinsi Banten, ada satu aspek yang masih dalam kategori rendah, yakni aspek hak-hak politik. Selanjutnya, ada dua variabel yang mempengaruhi aspek hak-hak politik, yakni : variabel hak di pilih dan memilih mendapatkan indeks sebesar 52,07

(rendah); dan variabel partisipasi politik dalam pengambilan keputusan dan pengawasan mendapatkan indeks 
sebesar 46,86 (rendah). Kondisi rendahnya aspek hak-hak politik di Provinsi Banten disebabkan oleh 2 (dua) faktor, yakni : Pertama, kejadian yang menujukkan ketiadaan atau kekurangan fasilitas sehingga kelompok penyandang cacat tidak menggunakan hak memilih; dan yang Kedua, adalah kualitas daftar pemilih (DPT) yang tidak baik. Sementara itu, yang menyebabkan variabel partisipasi politik dalam pengambilan keputusan dan pengawasan di Provinsi Banten mendapatkan indeks yang rendah adalah Pengaduan masyarakat mengenai penyelnggaraan pemerintahan.

\section{Fenomena Oligarki Politik Keluarga di Provinsi Banten}

Buruknya sistem demokratisasi lokal di Banten salah satunya juga di oleh fenomena oligarki politik keluarga di Provinsi ini. Saat ini Fenomena oligarki politik keluarga di Provinsi Banten merupakan fenomena yang sedang hangat dibicarakan oleh pengamat politik, politisi, dan penikmat politik, baik secara lokal, nasional maupun secara internasional. Bahkan ada ungkapan "jika mau belajar politik dinasti maka belajarlah ke Provinsi Banten". Ungkapan tersebut tentu bukan ungkapan yang "isapan jempol", tetapi faktanya demikian. Salah satu keluarga yang menenpatkan keluarganya menguasai kekuasaan politik lokal di Provinsi Banten baik di legislatif maupun di eksekutif adalah keluarga Ratu Atut Choisyah (Gubernur Banten), gambaran tersebut terlihat pada tabel di bawah ini :
Tabel 1

Oligarki Keluarga Ratu Atut Choisyah (Gubernur Banten)

\begin{tabular}{|c|c|c|c|c|}
\hline No & Nama & Hubungan & Jabatan & Keterangan \\
\hline 1. & Hikmat Tomet & Suami & $\begin{array}{l}\text { Anggota DPR- } \\
\text { RI dan Ketua } \\
\text { DPD Partai } \\
\text { Golkar Banten }\end{array}$ & $\begin{array}{c}\text { Mencalonkan } \\
\text { kembali menjadi } \\
\text { anggota DPR-RI } \\
\text { pada tahun } 2014 \\
\text { dari dapil Banten } 2\end{array}$ \\
\hline 2. & Andika Hazrumy & Anak & $\begin{array}{l}\text { Anggota DPD } \\
\text { dan Ketua } \\
\text { Karang Taruna }\end{array}$ & $\begin{array}{c}\text { Mencalonkan } \\
\text { anggota DPR-RI } \\
\text { pada tahun } 2014 \\
\text { dapil Pandeglang- } \\
\text { Lebak }\end{array}$ \\
\hline 3. & $\begin{array}{l}\text { Ade Rossi } \\
\text { Khaerunisa }\end{array}$ & Menantu & $\begin{array}{c}\text { Anggota DPRD } \\
\text { Kota Serang dan } \\
\text { Menjabat } 10 \\
\text { Ketua } \\
\text { Organisasi }\end{array}$ & $\begin{array}{c}\text { Mencalonkan } \\
\text { anggota DPRD } \\
\text { Banten nomor urut } \\
1 \text { dari Partai } \\
\text { Golkar }\end{array}$ \\
\hline 4. & Ratna Komalasari & Ibu Tiri & $\begin{array}{l}\text { Anggota DPRD } \\
\text { Kota Serang }\end{array}$ & \\
\hline 5. & $\begin{array}{l}\text { Aden Abdul } \\
\text { Cholik Atur }\end{array}$ & Adik Ipar & $\begin{array}{l}\text { anggota DPRD } \\
\text { Provinsi Banten }\end{array}$ & \\
\hline 6. & $\begin{array}{c}\text { Andiara Aprilia } \\
\text { Hikmat }\end{array}$ & Anak & & $\begin{array}{l}\text { Mencalonkan } \\
\text { anggota DPD } \\
\text { nomor urut } 7\end{array}$ \\
\hline 7. & Tatu Chasanah & Kakak Kandung & $\begin{array}{c}\text { Menjabat } \\
\text { sebagai Wakil } \\
\text { Bupati Serang }\end{array}$ & \\
\hline 8. & Haerul Jaman & Kakak Tiri & $\begin{array}{c}\text { Menjabat } \\
\text { sebagai } \\
\text { Walikota Serang }\end{array}$ & $\begin{array}{c}\text { Terpilih kembali } \\
\text { menjadi Walikota } \\
\text { Serang kedua } \\
\text { kalinya }\end{array}$ \\
\hline 9. & $\begin{array}{l}\text { Airin Rachmi } \\
\text { Diany }\end{array}$ & Adik Ipar & $\begin{array}{c}\text { Menjabat } \\
\text { Walikota } \\
\text { Tangerang } \\
\text { Selatan }\end{array}$ & \\
\hline 10. & Heryani & Ibu Tiri & $\begin{array}{c}\text { Menjabat Wakil } \\
\text { Bupati } \\
\text { Pandeglang }\end{array}$ & \\
\hline
\end{tabular}

Sumber : Di ambil dari beberapa sumber tahun 2013

Data di atas menunjukkan bahwa demokratisasi lokal di Banten belum tumbuh secara demokratis serta telah dibajak oleh oligarkioligarki lokal yang merasionalitaskan sistem tersebut seakan-akan telah demokratis. Ada 12 orang keluarga yang menguasai dan akan menguasai kekuasaan politik lokal dan nasional yang berasal dari tersebut.

Ada beberapa faktor yang menjadikan kondisi tersebut terjadi, 
yakni : Pertama, kondisi budaya politik masyarakat Banten masih yang bersifat patron-klien, sehingga kekuasaan oligarki politik keluarga di Banten di dukung oleh sebagian masyarakat menengah yang sadar atau tidak sadar; Kedua, Peran partai politik sebagai pelaksana fungsi rekruitmen politik tidak berjalan secara baik, hal ini terlihat sistem rekruitmen yang hanya mengedepankan kemampuan finansial dan populeritas bukan berdasarkan atas kepabelitas dari seorang politisi tersebut dalam menjalankan fungsi politiknya demi mensejahterakan masyarakat. Kondisi tersebut jelas akan memberikan peluang bagi oligarki-oligarki politik keluarga untuk mendapatkan akses tersebut dalam partai politik, sebab hanya mereka yang mempunyai kemampuan finansial dan populeritas dalam mengusai kekuasaan di Banten; dan Ketiga, Fenomena kekuasaan oligarki politik keluarga masih dianggap wajar oleh sebagain orang dalam era demokratisasi, dengan alasan jika pencalonan dari kalangan kelurga tersebut didukung oleh masyarakat kenapa tidak. Oleh karena itu, kondisi tersebut jelas akan semakin menacapkan kekuasaan oligarki di tanah Banten.

\section{E. Penutup}

Sejatinya penerapan desentralisasi harus memberikan dampak positif bagi tumbuhnya pelaksanaan demokratisasi lokal di Provinsi Banten, bukan malah menciptkan oligarki politik keluarga. Kondisi tersebut juga, tidak boleh dirasionalitaskan sebagai konsekuensi perjalanan demokrasi yang nantinya malah akan mudah dimanipulasi untuk kepentingan penguasa.

Oleh karena itu, ada beberapa gerakan yang harus segera dilakukan, yakni : Pertama, segera lakukan pendidikan politik kepada pemilih muda untuk segera melogikan bahwa demokratisasi yang betul adalah demokrasi yang dapat memberikan dampak persamaan politik, akuntabilitas lokal, dan kepekaan lokal; Kedua, lakukan pengawasan yang transparan serta mengambarkan bahwa oligarki politik keluarga akan memanipulasi demokrasi untuk kepentingan kekuasaannya; dan Ketiga, harus dapat mendorong tokoh-tokoh yang dapat memberikan perubahan demokratisasi lokal di Provinsi Banten agar lebih baik.

\section{F. DAFTAR PUSTAKA}

\section{Buku}

UNDP. 2011. "Menakar Demokrasi di Indonesia ; Indeks Demokrasi Indonesia Tahun 2009", Jakarta, UNDP, BAPENAS RI

Romli, Lili. 2005. "Pilkada Langsung, Otonomi Daerah dan Demokrasi Lokal", Jurnal Analisis CSIS. Vol. 34, No. 3 September 2005

Ismanto. 2011. "Banten Menuju Keterbukaan Informasi : Best Practice KI", Serang, Proceeding Otonomi Daerah, LAB ANE FISIP Untirta 2013. "Kinerja Tata Kelola Provinsi Banten”, Indonesia governance index (IGI), 


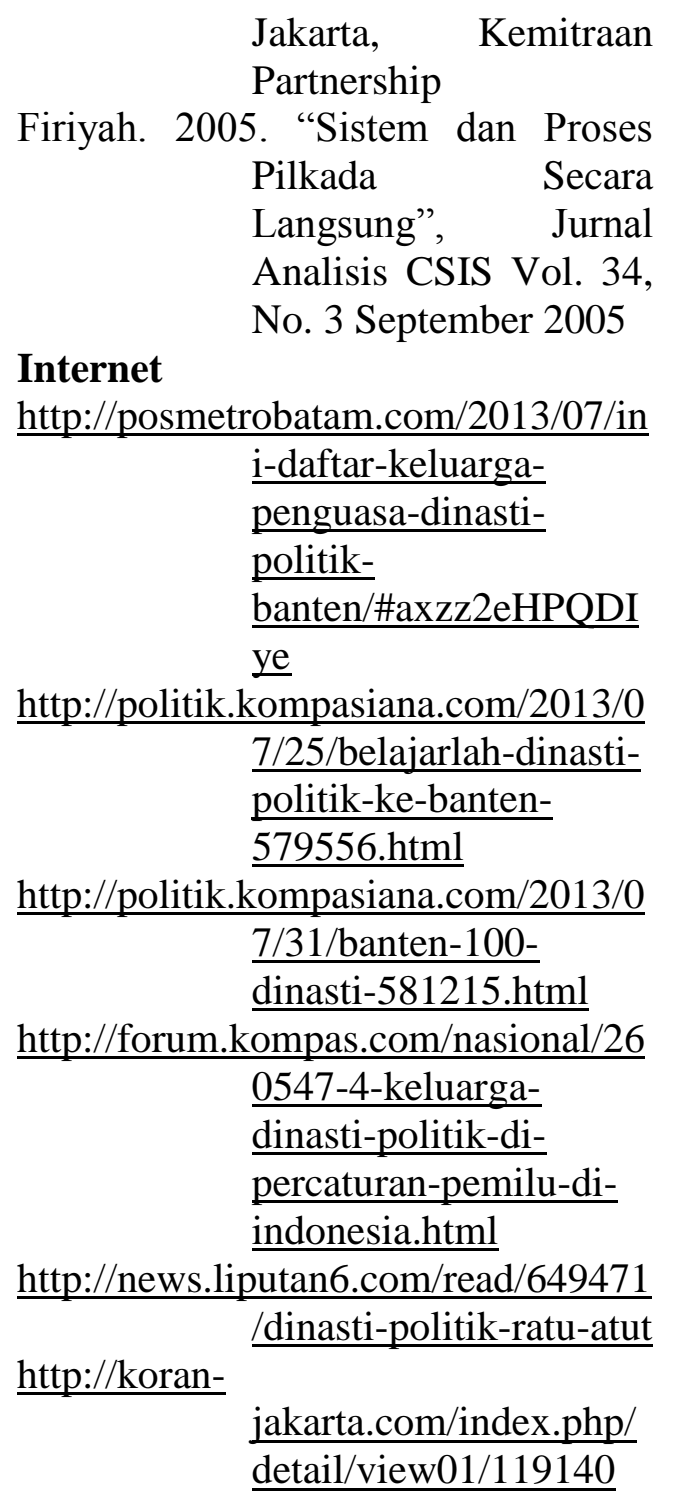




\title{
PARTISIPASI PEREMPUAN DALAM POLITIK DAN PEMBANGUNAN DI BANTEN
}

\author{
Oleh \\ Listyaningsih \\ Jurusan Ilmu Administrasi Negara Untirta
}

\begin{abstract}
ABSTRAK
Manusia sebagai warga negara merupakan subyek sekaligus obyek pembangunan di Indonesia. Namun, di tingkat daerah tidak demikian halnya, terutama di desa-desa yang masih jauh dari peradaban kota. Keberadaan perempuan belum terlihat nyata dalam setiap pergerakan pembangunan di Banten. Sehingga menarik peneliti untuk melakukan kajian lebih mendalam mengenai partisipasi perempuan dalam politik dan pembangunan di Banten. Penelitian ini dilakukan dengan menggunakan metode kualitatif dengan maksud untuk memudahkan peneliti dalam menjaring data-data kualitatif dalam bentuk eksplorasi. Hasil penelitian menunjukkan bahwa partisipasi perempuan dalam politik dan pembangunan masih tertinggal oleh kaum laki-laki yang disebabkan oleh dua faktor yaitu faktor struktural dan faktor kultural yang menyelimuti keadaal sosial, budaya dan politik di Propinsi Banten.
\end{abstract}

Kata Kunci: Partisipasi perempuan, politik dan pembangun

\section{A. PENDAHULUAN}

Pembangunan sebuah negara pada hakekatnya bertujuan untuk meningkatkan taraf kehidupan masyarakat berbangsa dan bernegara. Dalam pelaksanaannya, masyarakat tidak lagi menjadi obyek pembangunan, tetapi sudah menjadi subyek pembangunan. Sehingga peran serta masyarakat sangat menentukan berhasil tidaknya program-program pemerintah yang dijalankan. Peran serta masyarakat dapat berbentuk sumbangsih pikiran, tenaga atau keduanya. Namun ternyata, partisipasi masyarakat dalam pembangunan di Indonesia tidak seperti yang diharapkan kita bersama.

Rendahnya partisipasi perempuan dalam pembangunan daerah merupakan salah satu tema besar yang selalu muncul dalam diskursus mengenai reposisi peran perempuan dalam pembangunan dan politik. Salah satu aspek yang selalu muncul dalam diskursus ini adalah persoalan representasi kaum perempuan dalam struktur politik nasional maupun daerah, termasuk pula keterlibatan perempuan dalam proses perumusan kebijakan publik di pusat hingga daerah yang dirasakan belum cukup memadai. Persoalan ini muncul terutama bila membandingkannya secara dikotomis dengan eksistensi kaum perempuan dalam konteks kuantitatif yang ratarata sebanding dengan setengah populasi nasional maupun daerah.

Realitas partisipasi politik kaum perempuan di lembaga legislatif sejak tahun 1999 hingga 2004 yang baru berkisar pada angka 
$8,8 \%$ di tingkat pusat, $6,6 \%$ di tingkat Provinsi, dan $2 \%$ di tingkat Kabupaten/kota, merupakan gambaran nyata partisipasi perempuan dalam lembaga-lembaga politik formal yang sering digunakan sebagai dasar argumentasi pentingnya penguatan peran mereka melalui kebijakan-kebijakan yang besifat affirmatif terhadap potensi yang dimiliki kaum perempuan tersebut. Angka tersebut sedikit meningkat di tahun 2009 yaitu sebesar $11 \%$ di pusat dan $18,8 \%$ di tingkat Provinsi Banten, serta pada tingkat kabupaten dan kota rata-rata $13,7 \%$. (Bappeda Prov. Banten, 2010)

Menurut sumber Badan Kepegawaian Daerah Provinsi Banten (2009), diperoleh gambaran mengenai jumlah perempuan yang menjadi Pegawai Negeri Sipil (PNS)di lembaga pemerintahan di lingkungan Provinsi Banten hampir $50 \%$ dari jumlah pegawai laki-laki (1079:2202). Namun sangat sedikit pegawai perempun yang menduduki jabatan struktural. Dari data kepegawaian provinsi Banten tahun 2009 menunjukkan bahwa hanya 148 dari 1079 pegawai yang menduduki eselon I,II,III dan IV. Sementara jumlah laki-laki jauh lebih banyak yaitu sebesar 710 dari 2202 orang yang menduduki jabatan eselon I,II,III,dan IV.

Dalam konteks politik di Provinsi Banten, berdasarkan hasil Pemilihan Umum tahun 2009 diperoleh gambaran yang kurang lebih sama dengan realitas di atas, dimana ditemukan kenyataan proporsi anggota DPRD laki-laki jauh lebih besar $(82,4 \%)$ bila dibandingkan dengan jumlah perempuan yang hanya berkisar pada angka $17,7 \%$. Demikian juga pada kabupaten/kota yang ada di wilayah provinsi Banten. Di Kabupaten Pandeglang perempuan yang duduk dalam lembaga legislatif hanya sebesar 10\%, Kabupaten Tangerang sebesar 8\%, Kota Tangerang sebesar $12 \%$, Kota Cilegon sebesar 20\%, Kabupaten Lebak sebesar 16\%, Kota Serang sebesar17,8\%, Kabupaten Serang sekitar $8 \%$, dan Tangerang Selatan sebesar 15,6 \%. Jumlah ini tentu sangat ironis bila dibandingkan dengan jumlah pemilih perempuan yang hampir setara dengan pemilih laki-laki $(49,46 \%$ dan $50,54 \%)$ pada tahun 2009. (Bappeda Provinsi Banten 2010)

Kondisi inilah yang kemudian sering menimbulkan prasangka sosial adanya ketimpangan gender dalam pembangunan, yang direfleksikan dari realitas keterwakilan perempuan secara fisik dalam lembaga legislatif yang sangat minim, yang kemudian berpeluang pada tidak terwakilinya aspirasi kaum perempuan dalam proses perumusan kebijakan publik yang sensitif gender atau berpihak pada kepentingan perempuan maupun isu-isu yang terkait langsung dengan kehidupan dan hak-hak kaum perempuan. Isu-isu ini yang kemudian dikenal dengan isu-isu soft-politics atau conventional politics, yang dianggap menjadi domain kaum perempuan dan hanya dapat dipahami dan diempati oleh kaum perempuan. Isu-isu ini secara politik memang seringkali dianggap bukan sebagai isu politik sehingga nyaris tidak masuk dalam ranah kehidupan dan cara berpikir politik kaum laki-laki, yang antara lain 
menyangkut masalah-masalah: kesejahteraan anak, perlindungan terhadap hak reproduksi perempuan dan sebagainya. Dalam konteks inilah keyakinan terhadap keterlibatan perempuan secara lebih luas dalam politik menjadi sangat penting guna mengurangi kesenjangan antara isu-isu conventional politics dan hard politics. Hal ini cukup beralasan mengingat bahwa sikap politik kaum perempuan umumnya lebih cenderung mementingkan isu-isu conventional politics daripada hard politics. Sehingga sangat diperlukan sebuah kajian ilmiah mengenai partisipasi perempuan dalam politik dan pembangunan di Banten.

Dari latar belakang di atas kemudian menarik peneliti untuk lebih dalam mengkaji tentang bagaimana partisipasi perempuan dalam politik dan pembangunan di Banten. Adapun tujuan penelitian ini adalah sebagai berikut :

1. Mengetahui partisipasi perempuan dalam politik dan pembangunan di Propinsi Banten.

2. Mengetahui hambatan yang mempengaruhi partisipasi perempuan dalam bidang politik dan pembangunan.

\section{B. METODE PENELITIAN}

Dalam penelitian ini metode penelitian yang dilakukan adalah melalui pendekatan kualitatif. Artinya data yang dikumpulkan bukan berupa angka-angka, melainkan data tersebut berasal dari naskah wawancara, catatan lapangan, dokumen pribadi, catatan memo, dan dokumen resmi lainnya. Sehingga yang menjadi tujuan dari penelitian kualitatif ini adalah ingin menggambarkan realita empirik di balik fenomena secara mendalam, rinci dan tuntas. Oleh karena itu penggunaan pendekatan kualitatif dalam penelitian ini adalah dengan mencocokkan antara realita empirik dengan teori yang berlaku dengan menggunakkan metode diskriptif.

Dilihat dari pendekatan penelitian yang digunakan, instrument penelitian yang digunakan untuk mengumpulkan data dalam penelitian ini adalah peneliti sendiri. Oleh karena itu peneliti sebagai instrumen juga harus "divalidasi" seberapa jauh peneliti siap melakukan penelitian yang selanjutnya terjun kelapangan. Validasi terhadap peneliti sebagai instrumen meliputi validasi terhadap pemahaman metode penelitian kualitatif, penguasaan wawasan terhadap bidang yang diteliti, kesiapan peneliti untuk memasuki obyek penelitian baik secara akademik maupun logistik (Sugiono,2008:1).

Adapun data yang digunakan untuk analisis adalah pertama, data primer yang diperoleh melalui kegiatan wawancara dan dan observasi. Dan kedua, data sekunder yang diperoleh melalui dokumentasi dan kajian pustaka.

Untuk memastikan keabsahan data, penelitian ini menggunakan metode triangulasi. Metode triangulasi merupakan teknik pemeriksaan keabsahan data yang memanfaatkan sesuatu yang lain diluar data itu, untuk keperluan pengecekan atau pembanding terhadap data itu. Hal ini berarti membandingkan dan mengecek baik derajat kepercayaan suatu informasi yang diperoleh melalui waktu dan alat yang berbeda dalam metode 
kualitatif (Moleong,1990:175). Dalam penelitian ini metode triangulasi dilakukan peneliti dengan cara mengecek data melalui hasil wawancara dengan sumber pelitian yaitu: ibu rumah tangga, anggota DPRD yang perempuan, dan tokoh masyarakat di lokasi penelitian.

\section{HASIL PEMBAHASAN}

DAN

\section{Posisi Perempuan dalam Pembangunan dan Pemerintahan}

Sebuah tata pemerintahan yang demokratis meniscayakan adanya interaksi seluruh elemen dalam masyarakat dalam proses kepemerintahan. Interaksi yang konstruktif tersebut harus diakomodir oleh sistem politik tanpa diskriminasi, baik berdasarkan ras, agama, suku, status sosial-ekonomi maupun gender. Ada kesamaan hak dan kesempatan untuk setiap warga untuk berpartisipasi dalam prosesproses politik yang terjadi dalam sistem politik yang demokratis.

Umumnya keterlibatan warga dalam pengambilan keputusan publik sangat tergantung pada kemampuan suatu sistem politik untuk memberikan ruang-ruang kesempatan bagi setiap warganya dalam menyampaikan aspirasi tanpa mengenal batas ruang dan waktu, dan tanpa rasa takut. Kondisi ini tentu tidak akan dapat kita temukan dalam masyarakat yang sangat diwarnai oleh budaya patriarkhis, yang menempatkan nilai laki-laki pada posisi super-ordinate sehingga secara sengaja maupun tidak, dan langsung maupun tidak, telah mendiskriminasikan perempuan dalam proses politik.

Masalah pembagian peran sosiologis yang dikotomis antara lakilaki dan perempuan, dimana peran domestik distigmakan pada jenis kelamin perempuan sementara peran publik distigmakan pada jenis kelamin laki-laki. Kegiatan pemerintahan merupakan bagian dari peran publik yang menurut sebagian besar masyarakat "disunahkan" sebagai urusan perempuan. Adanya pembagian peran sosiologis yang rigid antara peran publik dan peran domestik tersebut tentu membuat posisi perempuan menjadi terpinggirkan.

Rendahnya keterlibatan

perempuan dalam proses pemerintahan telah terjadi sejak di tingkat paling rendah dalam strata pemerintahan yang ada, yaitu di tingkat RT, RW dan Desa. Sebagai bagian dari warga masyarakat di lingkungan tempat tinggalnya, umumnya para informan menyoroti persoalan keterbatasan kesempatan kaum perempuan untuk terlibat dalam forum-forum publik di lingkungannya, di samping secara teknis juga diakui kungkungan peran domestik yang dialami oleh mereka di dalam rumah tangga turut berperan besar dalam membatasi peran eksternal mereka, sehingga peranperan tersebut otomatis diserahkan sepenuhnya pada laki-laki sebagai kepala rumah tangga. Namun demikian, disamping kendala teknis tersebut, para informan pun umumnya sependapat bahwa komitmen kesungguhan para pelaku kebijakan untuk melibatkan perempuan memang tidak dimiliki 
oleh para pimpinan di tingkat RT, RW dan Desa. Gambaran tentang rendahnya komitmen tersebut termanifestasi dalam surat undangan yang hampir selalu berbunyi "Kepada Yth., Bapak Roni" atau "Kepada Yth., Bapak Ahmad", di samping penggunaan sebutan "Ibu Yatno" atau "Ibu $R W$ " untuk menggambarkan istri Bapak Yatno dan istri Bapak Ketua RW, bukan menyebut eksistensi diri individu yang bersangkutan, seperti "Ibu Romlah" sebagai nama istri Bapak Yatno, atau "Ibu Rodiah" sebagai nama istri Bapak Ketua RW.

Dalam pandangan para informan, fakta-fakta sosiologis tersebut merupakan wujud dari ketidakpahaman masyarakat akan kesamaan hak perempuan dalam pemerintahan yang kemudian sangat berdampak pada marginalisasi peran perempuan dalam pemerintahan, seolah surat undangan itu memang hanya buat Bapak dan Ibu tidak termasuk didalamnya. Fenomena ini tidak terlepas dari kerangka budaya patriarkhi yang telah menjadi mindset bagi sebagian besar masyarakat khususnya laki-laki. Laki-laki senantiasa diberi peran di ruang publik yang dinilai lebih penting daripada peran domestik. Dikotomi peran inilah yang kemudian pada akhirnya memposisikan perempuan menjadi tidak terlibat dan atau tidak dilibatkan dalam proses-proses publik tersebut.

Kendati beberapa perempuan mencoba muncul menjalankan peranperan publik, namun tetap saja kebanyakan hanya ditempatkan sebagai pelengkap semata. Situasi rapat yang sangat melelaki, lengkap dengan berbagai humor selera lakilaki yang kebanyakan mengeksploitasi seksualitas perempuan, secara psikologis kebanyakan membuat perempuan tidak betah berlama-lama dalam forum-forum tersebut. Walhasil perempuan kendati sudah masuk sektor publik, tetap saja masih menjalankan peran-peran yang masih terkait dengan peran domestiknya, misalnya sebagai MC, penerima tamu, seksi konsumsi, dan sebagainya.

Kemudian masalah-masalah seputar perempuan dan kesejahteraan keluarga di dalam ruang tertutup yang 'tidak boleh' mengemuka pada ruang publik, sehingga seringkali menempatkan masalah-masalah tersebut sebagai kepentingan yang sekunder, jauh dari hingar bingar pembahasan dalam rapat yang menjadi urusan laki-laki. Masalah kekerasan dalam rumah tangga misalnya, masalah kesehatan reproduksi, beban kerja dalam rumah tangga yang dialami perempuan, pendidikan anak, dan sebagainya dianggap bukan hal yang urgen untuk dibicarakan dalam forum-forum rapat. Beberapa isu bahkan dianggap mengandung nilai tabu didalamnya yang tidak boleh dibahas di ranah publik, kendati masyarakat pada umumnya memahami bahwa ada bentuk-bentuk kekerasan yang terjadi di lingkungannya. Karena kondisi inilah pada akhirnya nyaris tidak dapat dilakukan advokasi yang memadai ketika terjadi banyak kekerasan terhadap perempuan dan anak dalam rumah tangga. Semua masalah itu dianggap merupakan urusan intern "dalam negeri" yang 
sama sekali tidak boleh dicampuri oleh siapapun dan dengan alasan apapun. Dan yang lebih menyedihkan lagi adalah bahwa ternyata - menurut para informan - pemahaman tersebut juga ternyata dianut oleh sebagian besar kaum perempuan di Provinsi Banten, khususnya kaum perempuan di wilayah perdesaan yang persentasenya mencapai $80 \%$ dari populasi perempuan.

Lebih jauh lagi, dalam konteks toleransi masyarakat terhadap kaum perempuan yang terlibat dalam kegiatan-kegiatan sosial, menurut para informan terdapat adanya persepsi publik yang menggejala luas dikalangan perempuan bahwa seolah wajib hukumnya bagi perempuan untuk terlibat dalam kegiatan-kegiatan sosial seperti: PKK, Posyandu, dan majelis taklim, termasuk pula arisan. Persepsi ini menjadi semacam nilainilai baru yang mentradisi, dan itu dipahami sebagai obligative duty, bahwa istri kepala desa misalnya, harus otomatis harus menjadi ketua tim penggerak PKK. Demikian pula dengan perangkat-perangkat desa hingga tingkat RT/RW. Di lingkungan pekerjaan, istri seorang kepala kantor otomatis harus menjadi ketua Dharma Wanita, demikian pula dengan istriistri pegawai negeri biasa.

Karena persepsi "keharusan" inilah maka dalam bidang kegiatankegiatan sosial semacam ini memang harus diakui partisipasi kaum perempuan cukup tinggi, kendati menurut para informan baru pada aspek kuantitasnya saja. Artinya bila melihat jumlah perempuan yang terlibat dalam kegiatan sosial semacam itu, nampaknya nyaris semua kaum perempuan, khususnya di perdesaan, terlibat cukup intens dalam kegiatan-kegiatan tersebut. Namun bila melihat kualitasnya, keterlibatan tersebut belum tentu diiringi dengan pemahaman yang benar sehingga seringkali keterlibatan mereka didalamnya tidak memberikan nilai tambah yang berarti bagi peningkatan kualitas diri, kehidupannya, dan juga kehidupan keluarganya. Bagi sebagian kaum perempuan yang telah terbiasa mengikuti kegiatan-kegiatan tersebut maka umumnya keterlibatan mereka dalam kegiatan-kegiatan tersebut dianggap sebagi rutinitas, kebutuhan, dan sekaligus tanggung jawab. Namun bagi sebagian perempuan lainnya, yang umumnya keluargakeluarga muda, keterlibatan mereka dalam kegiatan-kegiatan sosial di desa bukan karena keinginan pribadi dan karena kebutuhan mereka namun lebih merupakan tuntutan peran sosial (expected role) yang berlaku di lingkungan masyarakatnya. Bahwa misalnya: ibu-ibu harus ikut arisan, PKK, atau majelis taklim misalnya.

Terpolanya bentuk partisipasi kaum perempuan sesuai dengan ranah urusannya sebagaimana dipaparkan di atas menggambarkan kembali kuatnya nilai-nilai masyarakat yang menempatkan peran perempuan untuk menjauh dari urusan-urusan publik. Dalam bidang politik, berkembang persepsi publik dalam masyarakat - khususnya kaum perempuan - yang memandang bahwa masalah politik bukanlah masalah atau tanggung jawab / kewajiban perempuan, seperti halnya masalah kewajiban mencari nafkah dalam keluarga yang bukan menjadi 
kewajiban perempuan melainkan kewajiban laki-laki. Perempuan dianggap kurang pantas terlibat dalam politik yang distigmakan 'kotor', dan hanya laki-laki yang boleh berurusan dengan yang 'kotorkotor' agar perempuan yang berperan sebagai ibu dan orang yang terdekat dengan anak tidak terkontaminasi dengan hal-hal yang dianggap kotor tersebut.

Berbicara mengenai

keterlibatan perempuan dalam wilayah publik, umumnya informan berpendapat bahwa keterlibatan perempuan dalam wilayah publik tidak muncul secara otonom, melainkan dipengaruhi oleh lingkungan terdekatnya, yang umumnya peranan itu dilakukan oleh suami. Informasi ini muncul ketika ditanyakan tentang motivasi awal kaum perempuan terlibat memasuki wilayah-wilayah publik seperti terlibat dalam partai politik dan sejenisnya. Umumnya informan berpendapat bahwa keterlibatan itu bukan karena kesengajaan dan kesadaran, melainkan 'keterpaksaan' karena peran sosial yang melekat pada diri suaminya masing-masing. Misalnya, bila suami kebetulan menjadi aktivis atau pengurus partai politik, maka umumnya istri secara otomatis ikut menjadi aktivis dan/ atau paling tidak menjadi pendukung suami sebagai pengurus partai politik. Dukungan dan keikutsertaan istri terhadap aktivitas suaminya tersebut pada suatu ketika akan berubah menjadi sangat aktif yang akhirnya membuka peluang bagi istri untuk secara definitif mendedikasikan diri sebagai pengurus partai politik, dan bahkan membangun karir politiknya.
Beberapa contoh kepala desa perempuan yang menggantikan suaminya yang dulu menjadi kepala desa, atau perempuan yang menjadi aktivis partai politik karena suaminya menjadi pengurus partai politik tersebut, serta perempuan yang menjadi pengusaha karena beberapa usaha suaminya tidak lagi dapat dikelola sendiri sehingga perlu melibatkan istri dan atau keluarganya yang lain, merupakan contoh faktual untuk menggambarkan keterlibatan kaum perempuan dalam ranah publik yang tidak otonom sebagaimana dipaparkan di atas.

Berkaca dari Pemilu 2009 yang belum lama berlalu diperoleh informasi bahwa kendati partisipasi politik mereka dalam Pemilu terbilang tinggi, namun keikutsertaan perempuan dalam pemilu ini diakui karena mengikuti pilihan keluarga (suami), hanya beberapa saja yang dilandasi motivasi kesengajaan secara sadar untuk terlibat dalam Pemilu karena menganggap 'tos wayahna', menjadi kebiasaan masyarakat yang seolah harus diikuti dan dimaknai sebagai hal yang menentukan dalam kehidupannya sebagai warga negara serta sebagai peluang bagi adanya perubahan bagi perbaikan nasib diri dan masyarakatnya.

Demikian pula dalam konteks pilihan politik perempuan yang umumnya tidak muncul secara otonom karena kesadaran kritisnya terhadap pilihan-pilihan yang ada, melainkan dipengaruhi oleh cara pandang dan pilihan suami mereka masing-masing. Namun demikian seluruh informan setuju dan mengakui bahwa fenomena ini mulai agak berubah pada pelaksanaan 
Pemilihan Presiden tahun lalu, yang menurut mereka mengindikasikan adanya "perlawanan perempuan" terhadap pilihan suami mereka, kendati itu dilakukan secara tertutup. Kecenderungan ibu-ibu dan kaum perempuan umumnya memilih calon yang populer dan memiliki penampilan fisik paling menarik, merupakan fakta mulai bekerjanya pilihan otonom kaum perempuan, kendati itu masih sangat jauh di bawah nilai pilihan kritis yang ideal.

\section{Persepsi tentang Partisipasi Politik dan Pembangunan}

Persepsi memainkan peranan yang sangat penting dalam menentukan kualitas partisipasi politik seseorang. Persepsi yang baik cenderung akan melahirkan sikapsikap simpati hingga empati yang kemudian berkorelasi dengan tipe partisipasi yang muncul. Sementara persepsi yang buruk cenderung akan melahirkan sikap antipati hingga apatisme. Untuk kepentingan praktis, telaahan mengenai persepsi juga penting dilakukan dalam rangka mengidentifikasi dan memetakan bagaimana gambaran partisipasi perempuan sebagaimana dipaparkan di muka.

Persepsi, - sebagaimana dijelaskan di muka - akan berpengaruh terhadap cara seseorang berperilaku dan bersikap terhadap suatu masalah atau isu. Demikian halnya persepsi perempuan terhadap partisipasi kaumnya dalam ranah publik, serta persepsi terhadap peranperan gendernya dalam masyarakat, akan mempengaruhi pula bagaimana mereka melakukan aktivitas keseharian mereka. Hal ini dapat dipahami karena persepsi muncul dari seperangkat nilai yang terkristalisasi dalam diri seseorang melalui berbagai proses interaksi sosial sebagai wahana transmisi (pendidikan) nilai yang berlangsung di lingkungan masyarakatnya.

Umumnya perempuan memiliki pandangan yang sama bahwa persepsi perempuan terhadap segala kegiatan atau urusan dalam ranah publik bukan merupakan kewajiban maupun tanggung jawabnya, seperti: masalah pemerintahan, pembangunan, politik, dan lain-lain. Dalam konteks masalah politik misalnya, politik umumnya dipersepsikan oleh kaum perempuan sebagai dunia yang kotor, penuh konspirasi dan intrik, keras, dan penuh tipu daya. Mengingat persepsi ini secara umum juga dipahami oleh kaum perempuan pada umumnya maka ia menjadi semacam referensi sosial yang membentuk mind-set kaum perempuan untuk kemudian menjauhi hal-hal tersebut. Akibatnya memang menyedihkan, jumlah perempuan yang terlibat dalam proses-proses politik yang masih dalam hitungan jari, baik di tingkat yang terendah seperti rapat-rapat RT/RW dan desa, hingga tingkat yang lebih tinggi seperti pengurus partai politik di tingkat anak cabang, cabang, daerah/wilayah, hingga nasional.

Namun demikian, ketika ditanyakan apakah keterlibatan perempuan yang sangat minim tersebut sebagai sesuatu yang lumrah atau wajar, yang terjadi secara alamiah, sebagian besar informan menganggap hal tersebut sebagai 
kewajaran mengingat pada umumnya kaum perempuan di perdesaan sudah sangat tesita waktu dan perhatiannya terhadap masalah-masalah keluarga sehingga kualitas dan intensitas keterlibatannya dalam ranah publik umumnya terpinggirkan secara alamiah. Dalam kaitan dengan itu, menurut para informan, peran perempuan sebenarnya jauh lebih berat karena ternyata perempuan tidak hanya menjalankan peran-peran domestik seperti yang selama ini dipahami, bahkan 3 peran sekaligus sebenarnya telah mereka jalankan. Artinya bila ada perempuan yang mampu eksis di ranah publik tanpa mengabaikan peran-peran alamiahnya berarti perempuan itu adalah perempuan luar biasa.

Ketiga peran yang dimaksud di atas yaitu: (1) peran domestik yang terkait dengan tanggung jawab mereka terhadap urusan-urusan rumah tangga seperti memasak, mengasuh anak, melayam suami dan lain-lain; (2) peran produktif yang terkait dengan tanggungjawab mereka dalam bidang ekonomi untuk menghasilkan uang dan meringankan beban ekonomi keluarga; dan (3) peran sosial yaitu tanggungjawab untuk melakukan kegiatan-kegiatan sosial kemasyarakatan mewakili keluarga, seperti berorganisasi dan berkumpul dengan kelompok masyarakat yang lain, kegiatan PKK, arisan, pengajian, posyandu, serta pengajian/ majelis taklim.

Secara umum ada pengakuan dari para informan bahwa peranperan domestik yang inheren dalam diri keperempuanan mereka secara alamiah tersebut diberi nilai yang Iebih rendah oleh laki-laki dan bahkan dianggap sebagai kewajiban semata, sementara peran-peran sosial dan produktif yang dilakukan perempuan harus selalu disesuaikan dengan stereoripe perempuan, dan tentu harus pula selalu berkorelasi dengan peran-peran domestik tersebut. Maka manakala suatu kegiatan tidak berkait dengan hal itu, seperti politik dan pemerintahan misalnya, maka otomatis kegiatan itu harus dijauhi oleh mereka, tidak diperbolehkan oleh suami, dan dianggap tidak patut di mata masyarakat.

Peran-peran domestik (reproduktif) yang dinilai Iebih rendah dari nilai-nilai produktif ini tentu berdampak pada terjadinya domestikasi peran perempuan menjauhkan peran perempuan dari arus politik yang sebenarnya tidak harus dan tidak ada kaitan sama sekali dengan soal-soal publik di atas. Dan karena peran-peran ini dianggap sebagai kewajiban semata maka peran-peran publiknya tidak dianggap penting, sekunder bahkan tertier, dan fakultatif karena hanya berfungsi untuk mengisi waktu luang atau membantu keluarga atau suami. Domestikasi peran perempuan ini berdampak pada lemahnya posisi tawar perempuan di wilayah publik, khususnya dalam pengambilan kebijakan-kebijakan politik yang mengarusutamakan gender hingga akhirnya perempuan menjadi tersubordinasi dalam masyarakat.

Dan ketika disinggung soal kasus seperti pentingnya perlindungan terhadap perempuan dan anak, kekerasan terhadap perempuan (seperti istri ditinggal menikah lagi, suami menikah tanpa 
sepengetahuan istri, dan bentuk kekerasan fisik maupun psikis kebetulan para informan mengaku belum pernah mengalaminya), hakhak reproduksi, dan sebagainya, mereka menganggapnya bukan hal yang khusus dan lebih penting dari hal-hal yang disebutkan di atas. Kalaupun itu penting, menurut mereka terjadi karena ada masalah dalam keluarga mereka baik sosial dan umumnya ekonomi, sehingga bukan masalah yang berdiri sendiri melainkan efek samping dari sejumlah masalah yang dialami oleh keluarga. Suami menikah lagi menurut mereka, umumnya karena ekonomi keluarga telah cukup mapan bahkan berlebih, sementara komunikasi sosial dalam keluarga tidak berjalan dengan sebagaimana mestinya. Suami berperilaku ringan tangan umumnya terjadi karena ekonomi keluarga dalam kondisi kurang memadai, istri tidak dapat membantu, dan secara sosial komunikasi dalam keluarga juga tidak harmonis. Semua dianggap sebagai masalah yang memang ada namun berada dalam wilayah privat yang wajar sebagai akibat dari sejumlah persoalan atau faktor eksternal lain, kendati mereka secara emosional umumnya menjawab tidak rela kalau suaminya kawin lagi atau main tangan walau tidak bisa berbuat apa-apa bila itu terjadi pada mereka.

\section{Faktor-faktor dan Masalah yang Menghambat}

Realitas rendahnya
keterlibatan perempuan dalam
aktivitas publik sebagaimana
dipaparkan pada bahasan sebelumnya
terjadi karena banyak faktor yang

saling berkait. Mengutip beberapa teori dalam beberapa sumber yang dikaitkan dengan fenomena yang ditemukan di lapangan paling tidak terdapat dua aspek hambatan yang mempengaruhi kualitas dan intensitas partisipasi perempuan dalam pembangunan, baik aspek daya akomodasi kultural maupun daya dukung struktural. Hambatanhambatan tersebut nampak dari berbagai praktek kehidupan sosial masyarakat yang cenderung menempatkan posisi perempuan dalam posisi marginal dengan melegitimasi peran domestik serta stereotipenya, yang muncul dalam bentuk adagium: "3 (tiga) ...ur", yaitu: dapur, sumur, kasur.

Persepsi publik perempuan yang minor terhadap tanggung jawabnya dalam ranah publik pun kemudian menyebabkan makin menjauhnya perempuan pada bidangbidang yang terkait dalam ranah publik tersebut. Politik dan pemerintahan misalnya, umumnya perempuan "alergi" terhadap aktivitas politik dalam pengertian partai politik. Mereka memandang politik sebagai aktivitas 'kotor' dan menjadi domain laki-laki sehingga politik menjadi sangat maskulin. Persepsi ini paling tidak dapat disimpulkan sebagai realitas kultural yang kurang akomodatif terhadap adanya partisipasi perempuan secara lebih luas dalam pembangunan. Perempuan dianggap tidak pantas dalam jabatanjabatan publik dan politik karena sifat-sifatnya yang halus dan memiliki tugas-tugas khusus di rumah. Bahkan tidak jarang larangan berpolitik ini muncul juga karena alasan kemampuan dan intelegensia 
perempuan yang dipersepsi selalu dibawah laki-laki, maupun alasanalasan agama yang bersifat doktriner. Hal-hal itulah yang kemudian menghegemoni partisipasi sebagai domain laki-laki, sebagai manifestasi dari akar budaya patriarkhi yang masih tersisa kuat dalam kehidupan masyarakat kita.

Masalah-masalah

sebagaimana disebutkan dimuka merupakan faktor kultural yang menghambat keterlibatan perempuan di dalam pembangunan. Sementara pada aspek yang berbeda, kebijakan yang kurang peka gender yang diputuskan oleh pengambil kebijakan yang tidak melibatkan perempuan, di samping merupakan produk kultur yang berkembang dalam masyarakat, secara faktual menjadi kendala struktural yang semakin mempersempit partisipasi perempuan dalam pembangunan.

\section{Faktor Kultural}

Rendahnya tingkat partisipasi perempuan dalam pembangunan daerah sebagaimana tergambarkan pada paparan sebelumnya paling tidak disebabkan oleh beberapa faktor, diantaranva adalah faktor kultural, yang berkaitan dengan konstruk tradisi yang berlaku di dalam masyarakat. Beberapa hambatan yang teridentifikasi mengemuka dalam sejumlah wawancara yang dilakukan dengan sejumlah informan dapat diklasifikasi sebagai berikut:

1) Persepsi perempuan umumnya terhadap sifat aktivitas politik yang identik dengan kegiatankegiatan rapat di malam hari, kompetisi yang ketat dan cenderung kotor serta menghalalkan segala cara, paradigma kalah-menang dalam politik, dan lain-lain, dianggap bertentangan dengan nilai yang berlaku di dalam masyarakat. Dan bagi perempuan hal ini bertentangan dengan "kodrat"nya;

2) Peran domestik yang dimaknai secara fatalistik menyebabkan berkurangnya kesempatan bagi perempuan untuk terlibat dalam sektor-sektor publik. Apalagi di tambah dengan kenyataan bahwa sebenarnya peran perempuan tidak hanya merupakan peran domestik karena dalam banyak kasus perempuan justru menjadi mitra kerja bagi suami dalam membantu perekonomian keluarga. Posisi subordinatif perempuan dalam susunan keluarga tampak dari kewajiban istri untuk tunduk patuh dan sebatas sebagai pelengkap jabatan suami, atau kepatuhan terhadap ketentuan suami atas peran publiknya;

3) Pandangan agama yang dimaknai cenderung membatasi peran perempuan dalam politik karena dianggap sudah terwakili oleh suami yang merupakan kepala keluarga. Pandangan yang didasari oleh keyakinan agama ini menyebabkan keterlibatan perempuan dalam aktivitas politik bukan lagi didasari keinginan untuk melakukan perubahan terhadap realitas sosial, namun lebih pada ibadah dan pengabdian, sehingga jarang sekali muncul tindakan yang bermakna untuk memperbaiki 
posisi perempuan dalam organisasi-organisasi politik tersebut.

\section{Faktor Struktural}

Di samping faktor-faktor kultural di atas, terdapat pula mekanisme struktural yang menjadi kendala bagi keterlibatan perempuan secara lebih luas dalam pembangunan. Dalam konteks Pemilu 2009 lalu sebagai bagian dari pembangunan politik misalnya, kendala struktural dalam sistem rekrutmen politik di tingkat partai politik yang tidak peka gender makin memperkecil peluang tampilnya kandidat calon legislatif perempuan. Fakta kurangnya kandidat perempuan pada sebagian besar partai politik merupakan indikasi kuat kendala struktural ini. Ditambah dengan sistem kaderisasi partai yang kurang membuka akses bagi perempuan untuk menduduki posisi-posisi strategis di dalam partai politik, yang makin memperkecil peluang peremuan untuk berkiprah di dalamnya. Kondisi tersebut tentu saja paradoksal dengan jumlah perempuan yang mencapai separuh jumlah penduduk Provinsi Banten, yang tentu karena ketidakterwakilinya perempuan secara fisik di lembaga legislatif tersebut berpeluang tidak terwakilinya pula aspirasi kaum perempuan dalam pembuatan kebijakan publik yang sensitif gender. Secara umum faktor eksternal yang banyak ditemukan sebagai kelemahan di bidang sosial ekonomi yang juga memperkecil kesempatan kaum perempuan untuk terlibat dalam pembangunan pada umumnya. Realitas kebanyakan perempuan di Banten yang pada umumnya berpendidikan rendah, hidup dalam kemiskinan atau lemah secara ekonomi merupakan kendala struktural perempuan untuk berpartisipasi dalam pembangunan melalui organisasi-organisasi massa maupun partai politik.

Kendala struktural berupa rendahnya tingkat pendidikan perempuan pada umumnya disinyalir oleh para informan sebagai faktor yang mempengaruhi kesiapan kaum perempuan secara umum untuk terlibat dalam wilayah publik dan pembangunan daerah. Kecenderungan seragamnya persepsi ini muncul ketika diskusi diarahkan pada kecilnya jumlah aktivis perempuan, baik dalam lembaga swadaya masyarakat, organisasi massa, maupun partai politik di semua tingkatan kepengurusan. Kebanyakan informan berpendapat bahwa sulit mendapatkan kader perempuan yang berkualitas dan berpendidikan, walaupun menurut mereka juga alasan ini tidak berdiri sendiri karena yang sulit sebenarnya bukan perempuan yang berpendidikan namun perempuan yang mau terjun di partai politik. Sementara kalaupun kemauan itu ada, terdapat sejumlah faktor lain yang menghambat tampilnya perempuan ke panggung politik, seperti soal senioritas dalam partai, jenjang kaderisasi yang subyektif, dan yang pasti adalah kemampuan ekonomi perempuan untuk memodali perannya dalam politik. Faktor-faktor itu menurut sebagian besar dari informasi saling terkait dan kompleks untuk kasus perempuan, berbeda 
dengan laki-laki. Beberapa informan yang terlibat dalam politik mengakui bahwa mereka dapat eksis dalam politik karena secara ekonomi tidak bergantung pada suami. Pun demikian dengan sebagian besar perempuan lainnya yang eksis dalam wilayah-wilayah publik, seperti pengurus asosiasi profesi, asosiasi pengusaha, dan sebagainya. Kendati mereka pun mengakui bahwa sebagian dari perempuan yang eksis tersebut dapat eksis karena awalnya mendapat dukungan (baca: modal) awal dari suami mereka yang telah lebih dahulu eksis dalam bidangnya, dan beberapa mapan secara ekonomi karena berasal dari keluarga (orang tua) yang juga mapan secara ekonomi.

Bila kemudian ditimbangtimbang antara faktor struktural dan kultural tersebut, umumnya informan berpendapat bahwa kendala kultural memang secara substansial jauh lebih terasa sebagai penghambat, sementara kendala struktural hanya menjadi pelengkap yang digunakan sebagai alasan yang terukur untuk membatasi peran perempuan. Kendala kultural dimaksud sebagian telah dipaparkan di atas, lainnya misalnya kebiasaan yang berlaku dalam aktivitas dalam ranah publik (termasuk politik) yang menurut mereka menuntut perhatian penuh dan seolah tidak bisa separuhseparuh, rapat-rapat penting pengambilan keputusan yang hampir pasti dilakukan di malam hari, rapatrapat yang pasti dipenuhi dengan kepulan asap rokok dan wedang kopi, rapat yang menghendaki kehadiran perempuan sebagai penyegar rapat semata, dan sebagainya merupakan bagian dari kultur aktivitas politik yang memperkecil ruang gerak perempuan. Pada tingkat yang paling kecil, pola ini pun diterapkan dalam rapat-rapat di tingkat $\mathrm{RT} / \mathrm{RW}$ hingga Desa, kendati ini dapat dimaklumi karena aktivitas pengurus RT/RW ini yang memang baru bisa dilakukan di sore hingga malam hari setelah seharian sibuk bekerja di kantornya masing-masing. Namun kebiasaan rapat yang tidak efisien, berlamalama hingga larut malam bahkan tak jarang diselingi atau diikuti oleh aktivitas yang tak perlu seperti main catur atau gaple, dan sebagainya; merupakan kultur laki-laki yang tidak akan bisa diikuti oleh perempuan mengingat pandangan sebagian besar masyarakat yang memposisikan peran domestik sebagai kodrat perempuan yang tidak bisa ditinggalkan.

Inilah fakta-fakta empiris yang dapat kita pahami untuk melihat realitas rendahnya partisipasi perempuan di sektor-sektor publik. Bisa jadi profil ini juga menjadi profil partisipasi perempuan di Provinsi Banten dan Indonesia pada umumnya mengingat beberapa prakondisi yang ditemukan di wilayah ini juga relevan dengan karakteristik di daerah lainnya, bahkan di Indonesia sekalipun. Kerelaan kaum laki-laki untuk mengakui kesamaan hak kaum perempuan dalam politik ternyata sangat mahal harganya. Maskulinitas yang mengakar kuat dalam kultur aktivitas publik merupakan gunung karang besar yang menghambat laju peningkaan partisipasi perempuan dalam pembangunan, walaupun kita tidak bisa menyimpulkan apakah ini sebuah kesengajaan dari desain 
budaya yang dikembangkan, ataukah sesuatu yang taken for granted sebagai bagian dari warisan kebudayaan masa lalu yang sudah mencapai taraf puncak dan berlaku universal. Penelitian lebih lanjut diperlukan untuk menjawab fenomena ini.

Dari eksplorasi yang dilakukan pada kedua fakta tersebut, diperoleh beberapa simpulan yang terkait dengan konteks penelitian ini sebagai berikut:

1. adalah realitas yang secara kasat mata dapat dibuktikan, bahwa tingkat partisipasi atau keterlibatan perempuan dalam aktivitas publik mulai dari tingkat RT, RW, desa, organisasi kemasyarakatan dan lain-lain masih sangat jauh dari harapan. Realitas ini terutama tampak dari kecenderungan adanya 'domestikasi' aktivitas publik kaum perempuan pada organisasiorganisasi sosial yang memiliki stereotipe sama dengan perempuan. Keaktifan perempuan diarahkan pada organisasi yang bersifat sosial dan seolah "diperuntukkan" khusus bagi perempuan dengan kegiatankegiatan yang bersifat khas dan mewadahi seluruh stereotipe perempuan. Akibatnya, aktivitas dalam organisasi ini cenderung hanya makin menguatkan peran domestik perempuan dalam organisasi-organisasi publik yang justru banyak memotivasi mereka untuk berperan lebih luas dalam ranah publik.

2. tumbuhnya persepsi publik yang meluas bahwa aktivitas peranperan publik yang identik dengan politik, yang dilakukan kaum perempuan bertentangan dengan kodrat keperempuanan mereka. Aktivitas politik yang berstereotipe maskulin: keras, penuh persaingan, penuh intrik dan konspirasi, bahkan 'kotor' dianggap tidak sesuai dengan kodrat fisiologis maupun psikologis perempuan. Belum lagi praktek-praktek dalam keseharian aktivitas politik yang semuanya melelaki, seperti rapat-rapat malam, rapat dan asap rokok, kekerasan yang kapanpun bisa terjadi dalam persaingan politik, semuanya seolah menjadi momok yang menakutkan bagi perempuan untuk terlibat di dalamnya.

3. terdapat pula fakta bahwa pengetahuan perempuan tentang partisipasinya pada sektor-sektor publik masih relatif terbatas, umumnya mereka kurang memahami eksistensi dan fungsi lembaga-lembaga pemerintahan desa, tugas dan mekanisme perannya, termasuk pula berbagai produk-produk kebijakan publik yang terkait dengan kehidupannya.

4. umumnya pula, terdapat anggapan bahwa peran domestik yang selama ini di-titi kaum perempuan sebagai jalan hidup adalah sebuah keniscayaan yang harus dimaknai sebagai dedikasi terhadap peran yang bersifat given ini, bahkan ibadah yang bernilai transedental. Mereka tidak memandang khusus dan penting adanya perjuangan bagi kepentingan kaum perempuan karena menganggapnya telah inheren dalam perjuangan 
memperbaiki kesejahteraan

masyarakat, meningkatkan

aksesibilitas pendidikan dan pelayanan kesehatan dan lainlain.

5. Terdapat beberapa faktor dan sejumlah masalah yang mempengaruhi partisipasi kaum perempuan dalam aktivitas publik. Namun dari sejumlah kecenderungan pandangan para informan sebagaimana dipaparkan di atas menunjukkan faktor kultural dan masalahmasalah yang timbul di dalamnya merupakan faktor yang mempengaruhi secara dominan terhadap rendahnya partisipasi perempuan dalam pembangunan daerah, antara lain misalnya:

- Faktor religi yang menempatkan perempuan secara kodrati (wajib) dengan peran utama pada peran domestik, dan peran lain sebagai peran sekunder yang tidak harus (sunnah) dilakukan atau membutuhkan prasyarat yang terpenuhi untuk terlibat didalamnya ;

- Budaya masyarakat yang tercermin dari mind-set yang telah mentradisi bahwa aktivitas publik yang identik dengan politik adalah aktivitas laki-laki dengan stereotipe maskulin, yang tidak cocok dengan aspek fisiologis dan psikologis kaum perempuan;

\section{KESIMPULAN DAN SARAN}

Paparan fakta empiris di muka menghantarkan kita pada pemahaman baru mengenai realitas partisipasi perempuan dalam pembangunan daerah di Propinsi Banten, untuk kemudian dapat dirumuskan saran yang bersifat rekomendatif guna memperbaikinya di masa yang akan datang. Beberapa saran yang dapat peneliti rumuskan adalah sebagai berikut:

1. Perlunya dilakukan pendidikan politik yang mengarusutamakan gender secara benar melalui organisasi-organisasi yang banyak diminati oleh kaum perempuan untuk beraktivitas di wilayah tersebut, misalnya majelis taklim, organisasiorganisasi arisan, PKK, dan organisasi sosial lainnya;

2. Pendidikan politik yang sama perlu dilakukan terhadap lakilaki: kepala keluarga dan remaja putra guna menjaga keseimbangan pemahaman tentang kesetaraan gender dan bias gender yang selama ini terjadi dalam kehidupan bermasyarakat di lingkungan mereka;

3. mendorong adanya kebijakan dalam praktek tata pemerintahan di desa untuk sensitif gender, dengan tidak mendikotomikan peran laki-laki dan perempuan pada pembagian kerja di unitunit kerjanya;

4. dan dalam jangka panjang perlu adanya rumusan yang tepat dalam kurikulum pendidikan kita guna menanamkan nilai-nilai kesetaraan gender dalam diri generasi muda sehingga secara perlahan dapat merubah mind-set masyarakat yang telanjur kurang berpihak pada perempuan, khususnya dalam peran-peran publik. Pendidikan berwawasan 
gender harus dapat mewujudkan (a) Menerima perbedaan kodrati individu, laki-laki dan perempuan sebagai hikmah,sehingga berperilaku adil dan tidak adanya pembedaan perlakuan antara laki-laki dan perempuan baik di rumah, di tempat kerja maupun di masyarakat (b) Memahami kondisi hidup laki-laki dan perempuan berbeda, bahwa perbedaan itu pada dasarnya karena fungsi kodrati.

Akhirnya semoga remokendasi ini dapat menjadi concern kita bersama guna melakukan upaya-upaya perubahan dari hal-hal yang kecil, dari diri kita sendiri, dan dari sekarang sedemikian rupa sehingga ke depan dapat memberikan kontribusi yang nyata bagi perbaikan dalam tata kehidupan masyarakat. Amien.

\section{E. DAFTAR PUSTAKA}

Alfian. 1990. Masalah Dan Prospek Pembangunan Politik Indonesia, Jakarta: Gramedia

Bappeda Provinsi Banten, 2010, laporan tahun 2010.

CETRO (Centre For Electoral Reform). 2002. "Data dan Fakta Keterwakilan Perempuan Indonesia di Partai Politik dan Lembaga Legislatif, 1999-2001" (Ringkasan Eksekutif), Jakarta: Divisi Perempuan dan Pemilu. 8 Maret ( tidak diterbitkan).

Gaffar, Affan. 2004. Politik Indonesia Transisi Menuju Demokrasi, Jakarta: Pustaka Pelajar,
Hungtinton, Samuel P. dan Nelson, J. 1990. Partisipasi Politik di Negara Berkembang, Jakarta:Rineka Cipta

Parawansa, Khofifah Indar. 2003. Studi Kasus: Hambatan terhadap Partisipasi Politik Perempuan di Indonesia, makalah

Rush, Michael. dan Althoff. 1993. Pengantar Sosiologi Politik. Jakarta: Raja Grafindo Persada

Saptari, Ratna. dan Holzner. 1997. Perempuan, Kerja dan Perubahan Sosial, Jakarta: Pustaka Utama Graffiti.

Soekanto, Soerjono. dan Lestarini Ratih. 1988. Fungsionalisme dan Teori Konflik dalam Perkembangan Sosiologi, Jakarta: Sinar Grafika

Sugiatri, dkk. 2003. Pembangunan Dalam Perspektif Gender, Malang: UMM Press.

Sugiyono, 2008, Memahami Penelitian Kualitatif, Bandung: Alfabeta

UNDP. 2003. Partisipasi Politik Perempuan Dan Tata Pemerintahan yang Baik: Tantangan Abad 21, UNDP. 